\title{
Prevalence and distribution of Tomato leaf curl virus in major agroclimatic zones of Gujarat
}

\author{
M. Shelat ${ }^{1}$, S. Murari ${ }^{1}$, M. C. Sharma ${ }^{1}$, R. B. Subramanian ${ }^{2}$, J. Jummanah ${ }^{3}$, B. Jarullah ${ }^{1}$ \\ ${ }^{1}$ Department of Biotechnology, Kadi Sarva Vishwavidyalaya, Gandhinagar, India \\ ${ }^{2}$ BRD School of Biosciences, Sardar Patel University, Vallabh Vidyanagar, India \\ ${ }^{3}$ King Fahd Medical Research Center, King Abdulaziz University, Jeddah, KSA \\ Email: bjarullah@yahoo.com
}

Received 10 September 2013; revised 28 November 28, 2013; accepted 19 December 2013

Copyright (C) 2014 M. Shelat et al. This is an open access article distributed under the Creative Commons Attribution License, which permits unrestricted use, distribution, and reproduction in any medium, provided the original work is properly cited. In accordance of the Creative Commons Attribution License all Copyrights (C) 2014 are reserved for SCIRP and the owner of the intellectual property M. Shelat et al. All Copyright (C) 2014 are guarded by law and by SCIRP as a guardian.

\section{ABSTRACT}

A study was conducted to establish the prevalence and severity of Tomato leaf curl viral disease in the major agroclimatic tomato cultivating regions of Gujarat. Districts of Gandhinagar, Kheda, Mehsana, Panchmahal and Rajkot of Gujarat were surveyed. The survey aimed at assessing types of symptoms, severity and yield loss in the tomato plants. Results obtained indicate vast spread of Tomato leaf curl virus in majority of the tomato fields in Gujarat. The maximum infection was observed in the Kheda district with almost complete crop loss followed by Mehasna and Gandhinagar districts showing high prevalence of infection. Influence of the climatic conditions and cultural practices were observed on the level of infection.

\section{KEYWORDS}

Field Survey; Geographical Distribution; TLCV; Yield Loss

\section{INTRODUCTION}

Tomato (Lycopersicon esculentum Mill.) is one of the most widely grown vegetable crops and popular due to its high nutritive value, taste and versatile use. It is a good source of vitamins (A and C) and minerals [1,2]. Total production of tomatoes is very high in India with Gujarat contributing approximately 22\% of annual production. Although the total cultivated area and production of tomato in Gujarat has increased gradually over last few years but productivity is still very low compared to the average yield of other states. Among the factors responsible for low yield of tomato, viral diseases are considered as the most serious. Tomato is susceptible to more than 200 diseases, out of which 40 are caused by viruses [3,4]. Among these viral diseases, Tomato leaf curl virus (TLCV) belonging to family Geminiviridae and genus Begomovirus is considered most devastating [2].

A recent socio-economic survey ranked Tomato leaf curl virus (TLCV), transmitted by B. tabaci, as the most important disease causing virus of tomato [5]. Epidemics of Tomato leaf curl virus associated with upsurge of whiteflies (Bemisiatabacci) on tomato crops has been frequently reported with up to $100 \%$ yield losses. There are 21 different types of Tomato leaf curl viruses found in India. Tomato leaf curl disease is manifested by yellowing of leaves, upward leaf curling, bushy growth, leaf distortion, shrinking of leaf surface, stunted plant growth, excessive branching, abnormal growth of plants and flower and fruit abscission. In 2001, TLCV was first reported in Gujarat by Chakraborty, S. et al. [6]. Recently, TLCV has become the prime limiting factor for tomato production in Gujarat. However, due to this virus studies on the prevalence and damage of tomato in Gujarat, have yet not been carried out. The present work therefore focuses on analysing the prevalence and severity of tomato leaf curl viral disease in different tomato growing regions of $\mathrm{Gu}-$ jarat.

\section{MATERIAL AND METHODS}

\subsection{Field Survey}

A survey was conducted in the major tomato growing regions of Gujarat. Five different regions were chosen and three different fields were studied from each region. In each visited field, three plots of size $10 \times 10 \mathrm{~m}$ were randomly selected. The overall disease incidence and severity was recorded based on visual symptoms. 


\subsection{Analysis of Symptoms}

Samples analyzed were observed for presence of Tomato leaf curl disease symptoms. Disease severity was scored using the scale of Horsefall and Barret with modifications, where: 1 = no disease, $2=1 \%$ - 3\% infection, $3=5 \%-12 \%$ infection, $4=12 \%-25 \%$ infection, $5=25 \%-50 \%$ infection and $6=>50 \%$ infection. Scores of $1-2$ were classified as low severity, 3 - 4 as moderate severity and 5 - 6 as high severity.

\subsection{Occurrence of $T L C V$}

Occurrence of $T L C V$ was determined by calculating the percentage viral infection for each plot observed. The percentage infected samples were calculated by dividing the infected samples with total number of samples.

\subsection{Statistical Analysis}

The field experimentation and the sample selection from the studied regions were carried out according to the standards of the Completely Randomized Design (CRD) [7]. The analysis of the data was conducted using the Two-Sample Tests of Proportions (TSTP) to compare the rate of occurrence of the virus in each of the studied regions. The results were then analysed using a level of significance when $\dot{\alpha}=0.05$.

\section{RESULTS AND DISCUSSION}

Based on the rainfall, soil and geographical situations Gujarat has been classified into eight major agroclimatic zones. The fields analysed in this study fell under four such zones. High occurrence of $T L C V$ infection was observed in all the studied fields of Gujarat. Maximum $T L C V$ infection was observed in Kheda district prevailing in the agroclimatic zone of Gujarat classified under middle Gujarat having deep black to loamy sand soil with average rainfall of $1000-1500 \mathrm{~mm}$. This was followed by Mehsana district and Gandhinagar district. Both these regions have been classified under North Gujarat known to have sandy loam to sandy soil with 625 - $875 \mathrm{~mm}$ of rain (Table 1).

Although variation was observed in the level of infection in two villages under the same district of Rajkot, these villages again have been classified into two different agroclimatic zones. Munjka is known to fall under the agroclimatic zone of Bhal and coastal regions having a high average rainfall of 625 - $1000 \mathrm{~mm}$ whereas Paddhari is known to fall under North Saurashtra characterized by low average rainfall of $400-700 \mathrm{~mm}$ and shallow medium black soil.

Two major factors known to be responsible for high $T L C V$ infection are cultural practices and climatic conditions. Our study thus supports reports of climatic influ-

Table 1. Occurrence of TLCD in different agroclimatic zones of Gujarat.

\begin{tabular}{|c|c|c|c|c|c|c|c|c|}
\hline $\begin{array}{l}\text { Sr. } \\
\text { No. }\end{array}$ & Districts & Town/Village & $\begin{array}{l}\text { Agroclimatic } \\
\text { Zone }^{*}\end{array}$ & $\begin{array}{l}\text { Cultivation } \\
\text { Practices }^{* *}\end{array}$ & $\begin{array}{c}\text { Field } \\
\text { No. }\end{array}$ & $\begin{array}{l}\text { Tomato } \\
\text { variety }\end{array}$ & $\begin{array}{l}\text { Average Percentage } \\
\text { of } T L C D \text { incidence }\end{array}$ & $\begin{array}{l}\text { Severity score } \\
\text { of } T L C V^{* * * *}\end{array}$ \\
\hline \multirow{3}{*}{ 1) } & \multirow{3}{*}{ Gandhinagar } & \multirow{3}{*}{ Chandrala } & \multirow{3}{*}{$\begin{array}{l}\text { North } \\
\text { Gujarat }\end{array}$} & $\begin{array}{l}\text { OFC with } \\
\text { Mulching }\end{array}$ & 1) & Abhinav & $50 \%$ & 6 \\
\hline & & & & OFC & 2) & Abhinav & $100 \%$ & 6 \\
\hline & & & & OFC & 3) & Abhinav & $100 \%$ & 6 \\
\hline \multirow{3}{*}{ 2) } & \multirow{3}{*}{ Kheda } & \multirow{3}{*}{ Nadiad } & \multirow{3}{*}{ Middle Gujarat } & OFC & 1) & Him Sohna & $100 \%$ & 6 \\
\hline & & & & OFC & 2) & Alankaar & $100 \%$ & 6 \\
\hline & & & & OFC & 3) & Alankaar & $100 \%$ & 6 \\
\hline \multirow{3}{*}{ 3) } & \multirow{3}{*}{ Mehsana } & Khanderavpura & \multirow{3}{*}{$\begin{array}{l}\text { North } \\
\text { Gujarat }\end{array}$} & OFC & 1) & Him Sohna & $80 \%$ & 6 \\
\hline & & \multirow{2}{*}{ Hirpura } & & OFC & 2) & Abhinav & $80 \%$ & 6 \\
\hline & & & & OFC & 3) & Abhinav & $60 \%$ & 6 \\
\hline 4) & Panchmahal & Godhra & Middle Gujarat & OFC & 1) & Namdhari & $60 \%$ & 6 \\
\hline \multirow{3}{*}{ 5) } & \multirow{3}{*}{ Rajkot } & Munjka & Bhal \& Coastal area & OFC & 1) & Desi & $100 \%$ & 6 \\
\hline & & \multirow{2}{*}{ Paddhari } & \multirow{2}{*}{ North Saurashtra } & OFC & 2) & US 440 & $80 \%$ & 6 \\
\hline & & & & OFC & 3) & Him Sohna & $70 \%$ & 6 \\
\hline
\end{tabular}

*In accordance with official report submitted by Directorate of economics and statistics (GUJCOST), Govt. of Gujarat under the heading "Horticulture in Gujarat 2009"; ${ }^{* *}$ OFC: OPEN FIELD CONDITION; ${ }^{* * *} 1=$ no disease, $2=1 \%-3 \%$ infection, $3=5 \%-12 \%$ infection, $4=12 \%-25 \%$ infection, $5=25 \%-50 \%$ infection and $6=>50 \%$ infection. 
ence on development of TLCV infection [8].

Level of infection in all fields falling under the same agroclimatic zone was found to be similar. However, one particular field of Gandhinagar region although growing the same variety of tomato plant showed half the level of infection as compared to other fields of Gandhinagar. Further inquiry into the cultural practices showed the utilization of mulching during cultivation in that particular field. The results further support the view that cultural practices greatly influence the level of infection of TLCV $[8,9]$. The overall prevalence of $T L C V$ infection was found to be very high.

Statistical analysis based on $\mathrm{T}$ test showed no significant difference observed among the plots of the same fields as well as the different fields of same regions.

\section{CONCLUSION}

Based on the above data, it can be concluded that TLCV infection is widely spread in all regions of Gujarat crafting a definitive need to control and manage the virus. Various factors such as climatic conditions and cultural practices play a vital role in the level of infection.

\section{ACKNOWLEDGEMENTS}

This project was in part supported by Gujarat State Biotechnology Mission (GSBTM), Gandhinagar.

\section{REFERENCES}

[1] Hobson, G.E. and Davies, J.N. (1971) The biochemistry of fruits and their products. Academic Press, New York.

[2] Kalloo, G. (1991) Genetic improvement of tomato. Springer verlag, Berlin Heidelberg. http://dx.doi.org/10.1007/978-3-642-84275-7

[3] Martelli, G.P. and Quacquarelli, A. (1982) The present status of tomato and pepper viruses. Acta Horticulturae, 127, 39-64.

[4] Lukyanenko, A.N. (1991) Disease Resistance in tomato. Springer verlag, Berlin Heidelberg.

[5] Chowda, R.V., Reddy, Colvin1, J., Muniyappa, V. and Seal, S. (2004) Diversity and distribution of begomoviruses infecting tomato in India. Archieves of Virology, 150, 845-867.

[6] Chakraborty, S., Pandey, P.K., Banerjee, M.K. and Kalloo, G. (2003) A New Begomovirus Species Causing Tomato Leaf Curl Disease in Varanasi India. Plant Disease, 93, 1485-1495.

[7] Lind, D., Marchal, W. and Wathen, S. (2005) Statistical Techniques in Business \& Economics. McGraw-Hill Irwin, New York.

[8] Polizzi, G. and Asero, C. (1994) Epidemiology and incidence of Tomato Yellow Leaf Curl Virus (TYLCV) in Greenhouse protected by screens in Italy. Acta Horticulturae (ISHS), 366, 345-352.

[9] Hilje, L., Costa, H.S. and Stansly, P.A. (2001) Cultural practices for managing Bemisiatabaci and associated viral diseases. Crop Protection, 20, 801-812. 